\title{
REVITALIZING CONVERSATIONS: LESSONS FROM AND ABOUT THE PRODUCTION OF INTERSUBJECTIVE AND INTERCULTURAL KNOWLEDGE
}

\author{
Claudia Briones \\ National University of Rio Negro \\ Ana Margarita Ramos \\ National University of Rio Negro ${ }^{1}$
}

\begin{abstract}
Based on our present working-experience with a Mapuche kimche (sage) and a logko (spiritual and political leader), we aim at intervening in broader debates on the intersubjective and intercultural production of knowledge. To do so, we pay special attention to contemporary mandates and pervasive conceptions about forms of practicing a better, more proper anthropology. We approach the problem from three different viewpoints: (a) discomforts and disagreements with naturalized forms of initiating, certifying, informing, writing, citing, and authorizing knowledge; (b) the Mapuche etiquette to converse properly and its various bets on horizontality; (c) review of our own philosophy of language, particularly the concepts of translation and performativity.
\end{abstract}

KeY WoRds: Anthropological ethics; Co-authorship; Free, prior, and informed consent; Horizontal methodologies; Mapuche People

\section{INTENTIONS AND INITIAL AGREEMENTS}

In May 2019, Rosendo Huisca Melinao, Mauro Millan, and the authors of this article met in a house in San Carlos de Bariloche to talk about ngütram. Up until then, the two of us had defined ngütram as a Mapuche verbal discursive genre used for recounting verifiable events which could be employed in a conversation about the past or for recounting a historical narrative. As a result of our encounter, we decided that this definition was not only too

1 Translation by Joanne Rappaport, Georgetown University. 
limited, but that it also was indifferent to Mapuche philosophies of temporality, memory, and knowledge. We did not all share the same expectations of our meeting, but as anthropologists we hoped to deepen our understanding of ngütram, which we had already suspected was inadequate. We also anticipated that the four of us would co-author an article for a volume on Mapuche theories of discourse, with the aim of constructing and sharing a more complex and deeper appreciation of the nature of this important genre in Mapuche social life. We are still writing that text. Here we approach the experience of co-authorship as a context for thinking as anthropologists about what it means to co-labor (co-laborar) (Leiva \& Speed, 2008), co-reason (co-razonar) (Guerrero, 2007), and co-author (co-autorar), all concepts that developed out of the rise of horizontal research methodologies. ${ }^{2}$ While we focus our analysis on a particular context in which we agreed to a particular form of interaction, we seek to intervene with this experience in broader debates about the intersubjective and intercultural production of knowledge, as well as reflect on the conventions and widely accepted understandings of the craft of contemporary anthropologists.

Rosendo Huisca Melinao is an elder who has lived his entire life in Chile. He has vast experience working both in Mapuche arenas, where he is recognized as a kimche (knowledge-bearer); ${ }^{3}$ he has also worked in academics as an instructor and a "linguistic assistant," given his highly reflexive command of the philosophy, uses, and structure of Mapunzungun, which is usually translated as the Mapuche language, but which Rosendo proposes we understand as "the language of the living beings (vivientes) of the earth."4 Mauro Millan is a longko (political leader) in the Mapuche community of Pillan Mahuiza (Chubut Province, Argentina) and a long-time activist in defense of the rights of his people. We are anthropologists who have for many years accompanied Mapuche communities and organizations, conducted analyses of political and social processes, and practiced our discipline with a focus on the Mapuche-Tewelche people of northern Argentine Patagonia. Rosendo and Mauro have known each other for many years, dating back to when Mauro collaborated in a process of reclaiming the territory of a Mapuche family who were relatives of Rosendo's. Rosendo traveled on that occasion to Argentina to meet his kin, forging affective ties that continue to the present day. The two men share a long history of conversation and the exchange of experience, with Rosendo habitually sharing his advice on

\footnotetext{
${ }^{2}$ Translator's note: The Spanish "co-laborar" is a play on the literal translation, "colaborar"; it expands on the meaning of "colaborar" by associating it with notion of working together," and suggests collaborative research is a form of labor. "Co-razonar" in Spanish brings to mind "corazón," or "heart."

${ }^{3}$ Although along the text we will make clear that any linear translation betrays the arguments that we are going to develop here.

${ }^{4}$ One of the concepts that Rosendo brought to our discussion at the first meeting was that of mapu. Several times, he questioned the fixity that adheres to its possible translation into Spanish as "land" and pointed out that this equivalency results in a loss of meaning. He explained that "mapu" refers to land as something concrete and tangible, such as, for example "the area in which one lives, one's domicile," or "the face of the earth, if you will." He then called our attention to the institutionalized and habitual uses of the term. For example, when "mapu" appears in the word "Mapuzungun" it does not refer to the Mapuche language, but instead, to the act of speaking about land. In its more profound sense, when "land" is associated with territory, with "the living beings of the land" ("los existentes de la tierra"), or with "a way of life, of being, a way of thinking and acting," you use "mapun" instead of "mapu." This is why he translated Mapunzungun as the language of the living beings of the earth, and why when he spoke he referred to "mapun" usages or "mapun" knowledge. We have endeavored to apply these uses and meanings in our text.
} 
how to interpret or talk about particular life events according to Mapuche precepts with Mauro, while Mauro shares his experience of the customs of Pwelmapu, the portion of Mapuche ancestral territory (Wall Mapu) lying to the east of the Andean Cordillera in Argentina. For many years, we have been building spaces of reflection with Mauro and Rosendo. Even though we have had fewer opportunities to get to know Rosendo, we enjoy a common array of professional relationships and friendships arising out of Mapuche activities.

Rosendo and his wife, Alicia, crossed the Cordillera to meet for three days with Mauro and us with the explicit and shared goal of thinking about, and co-writing a chapter on ngütram for an academic publication. Each of us had a different motive for joining the meeting. Rosendo and his wife enjoy traveling to meet with Mauro, but also appreciate talking with others who value equally the act of conversation. Mauro has been intent on "finding answers" from within the Mapuche philosophy of ngütram in order to counter the oversimplifications, stereotypes, and silences of the dominant historical narratives of the colonization of the Mapuche people, as well promoting Mapuche frameworks for interpreting history at various activist events. In spite of our years of work, we are especially interested in expanding our understanding of ngütram in order to retrospectively reevaluate what we are aware we still need to learn about kimün (knowledge) and az mapu (the organization of Mapuche life).

At our first breakfast, we began to discuss how to organize our exchange, based on a proposal that we had shared with Rosendo earlier over the telephone. According to Mapuche etiquette, which we tried to observe throughout our work and during periods of relaxation, Mauro would occupy the role of mediator and would serve as the principal host of the meeting. He initiated our conversation by sharing his own expectations of our encounter:

For me, I find answers at my meetings with Alicia and Rosendo. Because we feel a real absence, peñi [brother of a male, term of address to a male Mapuche by another man], because here, we lack a kimche who can provide us with answers. It's hard for us to create spaces of reflection. So, for me, especially, it will be important to write together about these topics.

Rosendo did not hesitate to alert us to the fact that writing cannot possibly encompass all of what happens and what we accomplish when we converse. This is something we came to understand later. Nonetheless, he and Mauro agree on the importance of leaving a written record for future generations. As Rosendo elaborates:

My daughter tells me that we need to write because what we say will be lost. Because, you see... Our longko thinks that you lose more by writing than by not writing. But I notice that my daughter is very excited about doing this, about writing down what she's learned from us. That's just to say that knowledge doesn't belong only to individuals. What happens is that when you write or register something in writing, it's there for the future, someone will see it. And someone will think it's important. 
This was not the only time we would reflect metadiscursively on the meaning and goals of our conversations, the expectations we each brought to the table, and how to be more successful in our objectives. We sought to harness friendship with the goal of achieving symmetry and respect in our interactions, something that is uncommon in Chile and Argentina in everyday exchanges between Mapuches and non-Mapuches. In the course of our efforts, Mapuche philosophies of language and of life, especially notions of translation and performativity, led us toward ways of understanding and practicing how to be together that we had not expected. In addition, we were compelled to think in new ways about how professional ethics influence the development of horizontal relationships, recognition of the equality of forms of knowledge, and learning to live with opacity without denying it nor trying to domesticate it. We will touch on each of these topics in the following sections.

\section{The 'Hows' And 'Whys': Sharing Discomfort, GaUging Emphasis, InTRoducing Agendas}

On occasion, Rosendo would draw on his previous involvements with academics in order to orient our conversation by inviting us to dwell on our personal experience as well as the centrality of discomfort as a way of thinking about our relationship. As we shared our opinions on the process of obtaining free and informed consent, working in co-authorship, and our different understandings of what they meant from the standpoint of "native Indigenous knowledge," we came to a common understanding of what it is to work in a collaboration between academics and others. This enabled us to reflect on continuities in the role of the informant and the authority of academic credentials, as well as the presumptions that underpin writing and the meaning of attributions, thereby constructing, as Rosendo expressed it, the "tijerales"—-the roofbeams—of our exchange.

After Mauro summarized the motivations behind our work and our objectives, he opened a discussion about how and what we would work on in collaboration. One of us suggested an interest in "writing something that the four of us could write together." Rosendo immediately referred to his prior experiences with academics and shared his qualms with us:

Rosendo: I say this because I've had experience with foreigners who came to Chile and began to generate a lexicon with the first word that was spoken. They started with feyentun-no less than with feyentun - [which means] "if you accept me or don't accept me." Because they wanted me to accept them [to work with them] ... So, I tell you that what is important is to know how: how, what, for what end, and all the other things related to that.

Claudia: Probably that feyentun is what later came to be called prior, free, and informed consent.

Rosendo: That's it! It annoys me when they ask for it. Why do they ask it of me? It forces me to become the owner of what I've said, or to accept or not accept that [my words] can be published. Because my ancestors knew what they knew and they never gave it to me in writing: one knows, not because you're a scholar but because-just like that-those things come to mind! So, I reject giving my consent in writing. ... Emotionally, I don't like it. 
Consent is not only a procedure; it is an anthropological mandate meant to guarantee conditions of equality. Thus, it was important for us to understand why it generated such feelings of discomfort in Rosendo "from a sentimental point of view." He responded by explaining that for him, consent was a sort of "paperwork" triggering a unidirectional form of recognition founded in the value of the written document. He also remembered having to "be on paper" to obtain accreditation by the Ministry of Education as a speaker of Mapunzungun, and when a university professor rejected him as a teacher and source of knowledge because he lacked formal academic credentials to become the co-author of a paper she was writing. In this sense, consent is similar to many other practices imposed by winkas (non-Mapuches): it negates how Mapuches transmit and produce knowledge.

Rosendo also added that the notion of consent obscures the question of why is it the Mapuche who must certify acceptance of the non-Mapuche, even though it is supposed that "we are among equals." He was troubled by the multiple ways in which academic logic, even when it is intended to engage tools ensuring equality, continues to reproduce boundaries, inequalities, and asymmetries. In the course of our conversation, we returned numerous times on Rosendo's work experience with other colleagues, his concerns and his moments of dissatisfaction, all of which sharpened our desire to create a process of co-authorship that operates differently.

Just as consent is associated with the logic of "paperwork"-which led us to think about the premises underlying this particular type of certification-the process of co-authorship also prompted Rosendo to confront the anthropological logic of the "informant" and the "author." This brought to light yet another paradox that flies in the face of anthropological common sense, which assumes that when you invite the other to occupy the role of co-author you are fulfilling the ethical and methodological mandate of horizontality. Rosendo explained his uneasiness by comparing co-authorship with the habitual use of the word "intercultural". He pointed to the existence of universities that call themselves "intercultural" for the simple reason that they have some Indigenous instructors, but they never question the hierarchies of knowledge that exist in their curricula or in their pedagogy, nor the asymmetries in how faculty achievements and recognition are evaluated within and outside of the institution.

Correspondingly, when we inquired into the roles each of us occupies in our work, Rosendo clarified that if Mapuches simply issued monologues and the anthropologists transcribed, ordered, and wrote them, this joint activity would be premised on a commitment with an expiration date, given that at some moment in the future Mapuches "will need to become the authors of their own work." Clearly, Rosendo and Mauro's proposals regarding their relationship with us exceeds any ad hoc division of responsibilities.

Rosendo's major objection to the presumed role of the informant centers on a fact he vehemently condemned: that the Indigenous interlocutor is generally understood to be someone who "delivers" knowledge. Rosendo shared with us a personal experience that is very common among Mapuches. Years ago, he published a book co-authored with a wellknown anthropologist, which garnered critique from other Mapuches. Some criticized the fact that the anthropologist appeared as a co-author of a book whose content came 
unilaterally from Rosendo. Others raised the following question: "How does Rosendo feel about delivering kimun mapun [Mapuche knowledge] to an anthropologist?"

We know that the anthropological use of textual quotations-which insert the Indigenous voice into the text-appears to indicate an adherence to what was said, but since statements and their contextualizations are not controlled by the person being quoted, it is a mere discursive effect. Furthermore, Rosendo argued that such discursive effects can be particularly damaging to Indigenous people: "They make a statement and insert the quotation from the person, and the problem is that the peñi reads it as though I told it to the researcher." Hence, the Indigenous interlocutor is not only suspected of "delivering" knowledge to the winka, but also of revealing secrets or forms of speaking about "delicate" topics. Rosendo concluded by recounting to us his response to the peñi who had questioned him: "What I responded is that what one does is to converse about our topics." He then redirected that same response to us: "I'm not delivering anything to you because we're conversing."

Thus, as we conversed with Rosendo and Mauro about what we were doing together, how we should accomplish it, and to what ends, we brought to the surface divergent preoccupations and experiences that each of us internalized in a different way. We all wanted our exchange to be the most horizontal possible, but we recognized that the ways we proposed to achieve this did not necessarily coincide. We also realized that our divergences originated in the sociocultural meanings each of us ascribed to the practice of talking together-ngütramkan-and the centrality of conversation to the Mapuche philosophy of knowledge. In what follows, we offer Rosendo's thoughts on how we would set in motion our collaborative work, in spite of the awkwardness each of us was feeling.

First, regardless of the topic being discussed, we would not try to talk about how others do something, but instead, ask in the first person and on the basis of personal experience, how you do that thing, or how we do it? Our conversation taught us how to be knowledgeable about a topic because we participated as thinking people complete with the emotions, sentiments, and experiences that have shaped us. From this angle, conversation, as it was proposed to us by Rosendo and Mauro, not only realigns an affective relationship by bringing to bear our situated but diverse lives, but it also places us on an equal level. If Rosendo was uncomfortable with a request to sign the free and informed consent form, it is because he expected to frame our exchange as a ngütramkan, founded on an affective relationship between equals.

Second, those who participate in a conversation bear the weight of the teachings of the fütakeche: "because when we converse, the ancestors are also present." Rosendo declared that despite how "university people" think, the fact that the source of our knowledge has academic training is irrelevant: "So in order to emphasize my kimün-knowledge-I always say 'it was told by a person who is illiterate." The fundamental objective is to base what we say in reality. In this sense, you do not simply invoke what happened in the past, but instead, you employ a particular way of talking about the past, about how you learned about the topic: in other words, that someone told us about it. Definitively, Rosendo concluded, what is 
relevant about a conversation is never its occurrence in and of itself, or how it occurred in the past-we are not trying to return to the times of his grandmother-but the fact that his grandmother told him about it, because that is what made him into who he is: "The teachings that formed me and that are now the logic of my life and my Mapun thought." This is what is harnessed when someone converses about a topic with others.

Third, knowledge is constantly renewed in each conversation. So, in the process of agreeing on how to write together, Rosendo clarified that he has good memories of having written things on paper, especially about the pride that his father expressed in his writing. Nonetheless, citing the words of a Mapuche authority with whom he had discussed this topic, Rosendo insists that he considers that "in books, the tone and the topics are repeated," because books fix and label what issues will be covered. For this reason, we agreed that instead of embarking on a ngütramkan-an exchange in which one talks and the other listens without interrupting-it would be best to engage in a ngütramkawün, a dialogue in which we are all involved and in which we analyze a topic together in order to add to the knowledge we have about it.

During our exchanges, Rosendo and Mauro put into practice what they had explained in words. For example, when Claudia remembered her experiences in the Mapuche community of Ancatruz, mentioning the Pillañ Lelfün, the plain where rituals are held, they used it to clarify the agenda of our conversations:

Rosendo: Note that when you said that, you reminded me that Pillañ Lelfün is such a pretty word and it has so much meaning .... It's the idea of rakizuamwhat is beautiful, what you end up discovering. In the course of ngütramkawün it all comes out, without forcing it. It becomes a presence, ga. I heard that from him [from Mauro]. That's what I was trying to tell you about ngütramkawün.

Mauro: Right. Just as happened to me last night with Rosendo and Alicia, in our conversation. Because what ngütramkawün generates is kimün [knowledge], and that's the ultimate objective of all of this, the final outcome of all of what we're doing. Because, as I said, I had a pewma [a dream], right? I told it to a machi [a female spiritual consultant]. And the machi told me that it could be so. But at the same time, Alicia and Rosendo expanded on the topic last night, and now I see in a new light everything I had imagined.

In short, a ngütramkawün would allow us to define what we were going to say: "constructing the roofbeams of what we're going to do and the form it will take [azümzungun]," in order to finally arrive at a consensus (netuzungu) regarding what will be captured in our writing. But what is most important is the fact that Mauro knew that as a result of the conversation, he would "have more tools for speaking, more knowledge to transmit" to his people. Because, as Rosendo explained, when you converse in your own way and freely, you learn to fashion more refined opinions about things. Even though he is a kimche, Rosendo sees himself as someone who learns, recognizes, and reconnects in the course of a conversation. 
Mauro: Therefore, my personal opinion about what has been said. . . is that I am already aware of many of the concepts. ... I've heard them from the elders. But what we have been doing is to weave them anew, right?

Rosendo: Yes. For that reason, each trawün [meeting] isn't meant to repeat what was said earlier. It doesn't repeat in order to say the same thing again, but to refresh the idea.

Ana: Precisely.

Rosendo: We don't want to fall into the way young people say, "I already know about that and I don't have to listen to it again." That's not how it is. The kimche listens again, because it's a way of revitalizing himself, of arriving at a new idea. So, I can say, "Mauro said it and I hadn't known it, and [now] I'm renewed by that idea." Or, in the end, "it made me change-not change, but recognize, distinguish. The change in me is because I was disconnected from something, while he wasn't.

During the days we met (trawün) with Rosendo and Mauro, various points made by Sarah Corona Berkin (2012) concerning how to define a horizontal methodology became relevant. Corona Berkin's argument abandons the foundational conflict of anthropology-the inherent inequality between the researcher and the researched-to forge ties of reciprocity. In other words, "don't hide or annul forms of knowledge in order to gain self-knowledge in a dialogue with the other. Advocating equality in spite of difference, putting to the test the horizontal relationship, and permitting the expression of your own needs and those of others, are all ways of confronting conflict and finding new and negotiated ways of coexisting" (Corona Berkin, 2012, p. 94). In accordance with her proposal, our trawün revisited and questioned dominant forms of identifying voices as legitimate or illegitimate, as each of us stated who we were, without occupying the roles traditionally assumed in an ethnographic encounter. Nonetheless, it also became clear that the search for horizontality is far from being a preoccupation and responsibility exclusive to anthropologists. The asymmetries that are at play are unequal, and must be made explicit and worked on. A kimche, whom we all recognized as an authority with knowledge, and a longko, whom we also all recognized as a political and spiritual authority, asserted that they wanted to converse among themselves and with us because they hoped to come out transformed by the conversation. We thought we were proposing a new, horizontal way of working when, in reality, they were also building horizontality with us.

When Rosendo showed us how the consent procedure presupposes a paternalistic relationship that is contrary to the goals of collaborative work, he was also arguing against the emphasis on technical knowledge that goes into the definition of who each of us is, instead, placing center stage a type of experiential knowledge. From his perspective, horizontality not only springs from an agreement regarding our interests, but even more so, it derives from problematizing the ways we converse, which are themselves the product of concrete relationships and affective ties. 


\section{RECIPROCAL EFFORTS}

As an ordering principle of our exchange, horizontality was not limited to providing an avenue for flattening asymmetries but, instead, we transformed it into a commitment sustaining a range of different types of reciprocal efforts.

For the time being, Rosendo and Mauro assumed that we two would commit to avoiding two practices common to researchers: to classify everything and to rapidly seek credible equivalences. From the start, they never voiced this expectation, but it always guided our conversational practice. Later, they illustrated it with examples, such as on occasions when our exchange revealed that we were disposed to act differently from journalists, or from other anthropologists and linguists. Rosendo, being a kimche, a knowledge-bearer, had earlier dissolved the asymmetry in knowledge that existed between us. Only then, he offered us three examples of how reciprocal processes of teaching and learning should work. He described a process of "listening to recognize," in order to distinguish, change, or "refresh [actualizar] an idea," knowing that even listening yet again to what we believed we already knew "is a kind of refreshing." Rosendo explained that "there was something inside me that was disconnected." As his examples revealed, this is what impatient apprentices who seek immediate utility without valuing the training process do not see, or journalists who want five hundred years of history to be recounted in two minutes and with whom "we cannot continue to speak, because there is no dialogue," or anthropologists who win over their interlocutors by tiring them with the goal of obtaining their agreement on conceptual equivalents that do not account for Mapunche usages. ${ }^{5}$ Or, in Rosendo's words, professionals who "put words in your mouth, such as when they asking simply for a yes or no answer."

In any case, Rosendo's clarifications forced us to evaluate in retrospect that which had been made explicit more in the doing than in the speaking. Concretely, we realized that the efforts of our Mapuche interlocutors to recreate horizontality among us all were demonstrated in practice not words again and again. The two of them put their commitment into action through their patient decision to not respond directly to our questions, but to offer examples or associations, including a search for "minimal pairs" to highlight subtle differences that Mapunzungun makes between practices, which, in Spanish, are neither linguistically nor conceptually differentiated. This process of placing in action, through which Rosendo and Mauro shared with us the Mapuche philosophy of language, is what Derrida (1968) defines as operating by différance or deferral, displacement, as opposed to the shortcut of différence or difference, which stoops to finding quick transcriptions. In the process, they alerted us not only to the difficulties inherent in any translation, but also its political consequences. They explained through example: "the word 'kalku' is bewitched." When the notion of kaiku is translated as "witch" or hastily associated with the semantic space of "witchcraft," you lose sight of the fact that from a Mapun perspective, there is no compulsion to mistreat or disqualify people, but instead, to recognize the way each person is. This is the basis on which Rosendo explained his conviction that interculturality is a political term that "doesn't mesh

\footnotetext{
${ }^{5}$ For example, those who say about their mentor that "he is telling me something else! I'm looking for gold, and he's giving me stones, tin. . . but what I'm looking for is gold." They ignore the fact that "what is good, is good, and what is expensive, is expensive" and that, in order to learn something you need "to teach many other things."
} 
properly [no está hilando]." Because it only fuels the search for quick equivalencies that impoverish, instead of understanding, what the Mapun perspective contributes.

Plainly, Rosendo and Mauro's choice of repeatedly differing without providing immediate and punctual responses had nothing to do with deficiencies in their command of Mapunzungun and Spanish but, to the contrary, owes to their reflexive determination to honor a type of horizontality that allowed us to not be satisfied with whatever immediate association or translation appeared to be the most effective. Instead, they prodded us to make appropriate connections in order to identify what is truly disconnected. In other words, just as in Derridean différance, we would not settle for establishing semantic essences or equivalences, but would comprehend, pragmatically and reciprocally, the degree of perseverance required in order to achieve an intersubjective and "intercultural" production of knowledge, which cannot limited to "knowing the word but communicating nothing."

Rosendo hoped that we would make an effort equal to his own. He reminded us that when "I'm speaking in Spanish, I suffer when I translate what I would [want to] call rakizoam in Mapun, because I have to use a word in Spanish that isn't the same word." At first glance, Rosendo's distress arises out of his awareness that he is being violated when rakizoam is minimally translated as "thought." He appears to be glossing what Viveiros de Castro calls the work of making controlled equivocations. For Viveiros de Castro (2004), these are not errors, but "the condition of possibility and limit of the anthropological enterprise" (p. 5); they are the effects of differences in perspective and constitute a mode of communication par excellence between different perspectives that unfold "in the interval between different language games" (p. 11; emphasis in original).

Notwithstanding, we understand that Rosendo is telling us something else. First, he is indicating that our tenacity in attempting to control equivocation extends far beyond anthropologists. We are not speaking of mere "language games" or differences in perspective, but of built-in certainties of what Mapunzungun is and does. This is why Rosendo used examples: of how he could act as a gillatufe who presides over the gillatun ceremony, thanks to his linguistic competence. But he would not have the same effect because he is not a gillatufe, and only he who is destined to be one-which Rosendo is notcan cause his words to "do" what they should do. In the same way, he insisted that the four of us could talk about many things, but that we should not think we were referring to the things themselves; instead, we were only talking about them, because we don't have the knowledge of those born to be directly connected to these things, for example the machis. ${ }^{6}$

But Rosendo goes even further, insisting that we comprehend that sharing kuyfi ngütram (narratives of ancient times) told by the elders is not only an act of sharing knowledge from the past but of refreshing the az mapu (the way of being, the way things work well): "I quote them because when you talk, they're here. Because you feel them behind you." Mapunzungun's ability to make things present is a far cry from what we understand as the

\footnotetext{
${ }^{6}$ Longko and machi are some of the Mapuche ancestral authorities, whose roles and functions are associated with a deep knowledge of Mapuche philosophy. They are associated with the power of the land and with ancestral spirits, conducting ceremonies and spiritually and/or politically guiding Mapuche individuals and families.
} 
performative capacity of Spanish to bring something into being through reiteration, which is what Judith Butler (2011) argues in her discussion of the performative nature of identities. In contrast, according to Mapuche philosophy, conversation does not only recreate relationships to establish the limits between ourselves and outsiders, but it brings into view a diverse range of existing (existentes) or living (vivientes) beings whom we non-Mapuches consider as "non-human." While our constructivist notion of performativity transforms such presences into a mere discursive effect, Mapunzungun turns them into a state of being, a presence that harnesses the consequences of what happens among the living. For this reason, "it is not useful" to speak with just anyone about anything. For this reason, it is not good to speak just to speak, nor to speak without communicating. Rosendo and Mauro endeavored to make it clear that when circumstances allow a conversation to flow across different belongings and dissimilar experience, our efforts to communicate and comprehend demand that we not limit ourselves to looking for the best words to reveal difference. Instead, we should pay attention to the very process through which we are communicating and to zoom into that which is not immediately accessible across distinct languages and experiences.

Finally, Rosendo and Mauro tried to explain in different ways that there are no mere differences in perspective, but instead, there are ontological and epistemological boundaries (Briones, 2014) that bad translations-or, perhaps, any translation-cannot discern. It is not only that different languages have different ontological capacities, but that there are forms of knowledge to which not all languages are privy. In particular, az mapu is not a mere set of norms directing how things should be, something that can be objectified verbally; instead, it is the way everything functions and "for this reason must function, because it has been established this way [from its origins] and this is how it has always been, it's how the ancients always did it." Az mapu is, in turn, an "applied practice" because "in the pewma [dream], they came to say that this is how it was and you thus need to continue with it." Rosendo insisted in the same vein that perimontu is not a mere "vision" but "seeing the uncanny that is out there with your own eyes. So, this is what you. . what I am seeing with my eyes... Therein lies the importance of giving it importance. Because I'm questioning myself. Thus, the question, the person who questions, thinks when he questions [he laughs]."

In that invitation to continuously question ourselves and to think, we came to understand that more than advocating controlled mistakes, Rosendo was prodding us toward one of the goals of intersubjective and intercultural knowledge: a way of seeking co-knowledge by identifying and inhabiting ontological and epistemological boundaries in our very speech without allowing them to fold in on each other. That is to say, he is demanding that we accept and make explicit all of that which, definitively, we cannot know, understand, or interpret in our conversations. The significance of conversation lies in making new connections with what is disconnected inside of us, sometimes without us even noticing it.

\section{Revisiting Anthropological Practice}

We did not think at first that the work we did with Rosendo and Mauro would result in an article like this one, written by the anthropologists. From our perspective, we were motivated by the possibilities of co-working and co-reasoning in a horizontal manner about 
ngütram. However, as Rosendo had anticipated, masters always teach much more than their expertise. Conversing and "listening, listening, listening" steered us into making new connections that have led us to think about how to do better anthropology. We do not doubt that Rosendo and Mauro hope to interact with worthy anthropologists in their search for a cohort with which to think about things, but it is clear that co-theorizing with us about this particular topic was not something with which they were concerned. For this reason, we alone reflect on these issues.

Collaboration and horizontal methodologies are frequently debated among colleagues without recognizing that such initiatives are posed and problematized unilaterally; they are practices proposed from an academic position. It became evident that our commitment to "converse" within the parameters of Mapuche etiquette required that horizontality become an intentional practice, one that was patiently sustained by our interlocutors. Intended to energize $a z \mathrm{mapu}$, this etiquette called into practice that very horizontality each time we asked ourselves how to interpret the experiences that we were each sharing, each time another zungu (matter) was introduced into the conversation, and when further examples were offered in response to our questions, so that we would not be left with interpretations that most comfortably coincided with our academic propensities to classify. In his role as a kimche, Rosendo replaced with Mapuche etiquette the usual model of interaction based on unilateral explication and immediate translation that we tend to use to express complex concepts in other words and to clarify them as much as possible. His gesture turned us into participants in a form of constructing knowledge that exists side-by-side with uncertainty, because it involves continually talking about "applied practices" that seek to understand and be done in context according to what the az mapu indicates in each case, moment, and place.

It became clear to us that prior, free, and informed consultation and consent, which without doubt is a demand that Indigenous peoples have made in order to avoid being steamrolled by state and private agencies, cannot be straightforwardly translated into scientific practice. As a political demand, it requires recognition of a right and a position of parity that is normally denied, even in established academic work. But when working relationships grow out of previous affective relationships, as is usual in anthropological practice, if we unilaterally propose this sort of consultation and consent, we are demanding a unidirectional privilege that runs counter to the possibilities of co-producing knowledge.

Also important is the recognition that many knowledges are co-produced in the course of horizontal relationships. The most fruitful goal from a Mapuche perspective is that this process of co-production not require agreement on how to define or explain things, but commences a process that is open to everyone, in order to revitalize, renew, and transform our ideas as we connect with all that which had been disconnected in each of us. When we endeavor to come to agreement on certain statements, we need not align with or deny all of the ideological, epistemological, or ontological boundaries activated in the course of each zungu or item under discussion. Instead, we should launch joint efforts at exploring them, providing room for them to be exemplified, displaced, and elaborated on, so that we appreciate their density. In this way, the intersubjective intercultural production of knowledge becomes less of an attempt to create a unified body of shared-or even only 
juxtaposed-knowledge, than it comes to involve identification of and agreement over those reciprocal opacities we are identifying, including understanding what mental habits they are based on.

From the start, Rosendo and Mauro's ideas were more well defined than ours concerning which professional practices would interfere with our capacity to comprehend what they wanted to tell us. Without doubt, this is because Indigenous peoples are decades, perhaps centuries, ahead of us in recognizing that they have been the object of such practices, at the same time they are obliged to persevere in communicating and sustaining their own. For this reason, they patiently attempted to move us out of our comfort zone, at times laughing at our questions, sometimes introducing other examples, displacing their explanations, making them more complex, or directly denying what they saw as inadequate interpretations.

In sum, this other mode of conversing and thinking through what has been talked about led us to recognize that epistemicide or epistemic violence (Castro Gómez, 2005; Santos 2010) is not limited to the act of converting other bodies of knowledge into mere beliefs to be rejected as illegitimate knowledge. It also comes into play each time anthropological explanation neutralizes or seeks to domesticate other "applied practices" of knowing, comprehending, understanding, and making comprehensible to others, thereby circumventing other modes of world-making (Blaser, 2009) and the forms of agency on these practices are based (Holbraad et al.., 2014). That is to say, epistemicide operates each time an explication seeks to neutralize frictions, transforming the inevitable différance-the interval between ontological, epistemological, or even ideological intervals-into mere différence, by accommodating it to anthropological theories we use to perceive and ontologize what language is and does, what translations should achieve, and what performativity allows to bring into being. It happens each time we underestimate the suffering of Rosendo and Mauro when they translate kuyfi ngütram as a true story that merely evokes and remembers the words of the living (los existentes), in place of making them present; when we say that they performatively actualize orally transmitted knowledge instead of recognizing that they are regenerating az mapu each time they share it with us; when we state that in any case, our different perspectives are simple derivatives of "linguistic ideologies" (Woolard \& Schieffelin, 1994) instead of recognizing that Mapunzungun is the language of all the living of the earth and not only of the che, of human beings. Then, perhaps, our renunciation of the continuing exercise of epistemic violence can take the form of learning to navigate as anthropologists a suffering that coincides with desisting from accepting "linguistic ideologies" and "performativity" as hermeneutic or explanatory concepts, using them instead as heuristic aids for connecting in new ways what appears disconnected to us and for renewing anthropology in and by means of each ngütramkawün.

Our experience of conversing with Rosendo and Mauro leads us to conclude that the intercultural and intersubjective production of knowledge inevitably operates in different directions and dimensions, sometimes encountering points of convergence and on other occasions, producing distinct types of reconnections for each interlocutor. An anthropology committed to overturning epistemic inequalities must confront them in a mutual act of 
learning about how to explore, speak, and even sustain different types of dissent and friction. We believe that such expectations explain why, for our interlocutors, interculturality as it is commonly practiced "doesn't hold together," given that in habitual practice we do not recognize or promote different linguistic philosophies of how to converse, nor do we generally take the time necessary for establishing the zungu, the item we will discuss together, or recognize that a range of beings participate in conversation and for this reason, there are things that cannot be communicated to just anyone, at any moment or in any situation.

In any case, if we decided that our joint work with Rosendo and Mauro would take a brief detour so that we could write this article, it is because we understand that making a better anthropology is not on everyone's agenda. For us, who wish to find a space for forming attachments and for activism in our profession, it is yet another commitment that is worth keeping. It is a commitment that does not spring from the belief that understanding cultural diversity will increase our humanity, as Geertz would have it, but from the conviction that it is only by revising certainties and the disciplinary common sense we have inherited, abandoning our comfort zones, and throwing our autopilot off course, that we can become better anthropologists.

\section{REFERENCES}

Blaser, M. (2009). Political ontology: Cultural Studies without 'cultures'? Cultural Studies, 23(5-6), 873-896.

Briones, C. (2014). Navegando creativamente los mares del disenso para hacer otros compromisos epistemológicos y ontológicos. Cuadernos de Antropología Social, 40, 49-70.

Butler, J. (2011). Bodies that matter: On the discursive limits of sex. Routledge.

Castro Gómez, S. (2005). La hybris del punto cero. Bogotá: Editorial Pontificia Universidad Javeriana.

Corona Berkin, S. (2012). Notas para construir metodologías horizontales. In S. Corona Berkin, \& O. Kaltmeier (Eds.), En diálogo: Metodologías horizontales en ciencias sociales y culturales (pp. 85-110). Gedisa.

Corona Berkin, S., \& Kaltmeier, O. (Eds.). (2012). En diálogo. Metodologías horizontales en Ciencias Sociales y Culturales. Gedisa.

Derrida, J. (1968). La différance: Conférence prononcée à la Société française de Philosophie, le 27 janvier 1968. Théorie d'ensemble, 41-66. Ed. Seuil. 
Guerrero, P. (2007). CORAZONAR: Una antropología comprometida con la vida: Nuevas miradas desde Abya-Yala para la descolonización del poder, del saber y del ser. Asunción: Fondo Nacional de la Cultura y las Artes (FONDEC).

Holbraad, M., Pedersen, M.A., \& Viveiros, E. (2014). The Politics of Ontology: Anthropological Positions. Theorizing the Contemporary. https://culanth.org/ fieldsights/series/thepolitics-of-ontology Accessed 20 August 2015.

Leiva, X., \& Speed, S. (2008). Hacia la investigación descolonizada: nuestra experiencia de colabor. In X. Leyva, A. Burguete, \& S. Speed, (Eds.), Gobernar (en) la diversidad: experiencias indígenas desde América Latina. Hacia la investigación de colabor (pp. 3459). México D.F.: CIESAS, FLACSO Ecuador, and FLACSO Guatemala.

Santos, B. de Souza. (2010). Descolonizar el saber, reinventar el poder. Trilce Extensión Universitaria.

Viveiros de Castro, E. (2004). Perspectival anthropology and the method of controlled equivocation. Tipiti: Journal of the Society for the Anthropology of Lowland South America 2 (1), Article 1.

Woolard, K. A., \& Schieffelin, B. (1994). Language Ideology. Annual Review of Anthropology, 23(1), 55-82.

\section{BIOGRAPHICAL NOTE:}

Claudia Briones (PhD), anthropologist, is Principal Researcher (CONICET) and a Full Professor at the National University of Rio Negro (Universidad Nacional de Rio Negro), at the Institute for Research in Cultural Diversity and Processes of Change (IIDyPCa). Her articles and books focus on Indigenous rights and Indigenist politics in Argentina, and particularly involve the cultural production and political organization of the Mapuche-Tehuelche people.

Ana Margarita Ramos (PhD), anthropologist, is an independent researcher (CONICET) and a Full Professor at the National University of Rio Negro (Universidad Nacional de Rio Negro), at the Institute for Research in Cultural Diversity and Processes of Change (IIDyPCa). Her articles and books focus on political belongings and trajectories of Mapuche-Tehuelche groups in Patagonia, and on political-affective processes of memory restoration in contexts of subordination and violence. 